\title{
СУЧАСНИЙ СТАН I ПЕРСПЕКТИВИ РОЗВИТКУ ГАЛУЗІ КОЗІВНИЦТВА
}

\author{
Ковальчук Ірина Ігорівна \\ кандидат ветеринарних наук, старший викладач \\ Поліський національний університет \\ ORCID: 0000-0002-2421-7533 \\ E-mail: kovalchuk_ira0982@ukr.net \\ Ковальчук Ігор Васильович \\ кандидат сільськогосподарських наук, доцент \\ Поліський національний університет \\ ORCID:0000-0002-5775-4140 \\ E-mail: ikovalchuk_08@ukr.net \\ Морочківська Анастасія Валентинівна \\ здобувач ОС магістр \\ Поліський національний університет \\ ORCID: 0000-0002-2818-0950 \\ E-mail: morockivskanasta@gmail.com
}

Однією із галузей, що займає чільне місце у забезпеченні населення продуктами харчування є козівництво. У країнах із розвиненим тваринництвом, козівництво - це важлива галузь сільського господарства, що зумовлено ії поліпродуктивністю (джерело продуктів харчування - молоко, сири, жир і сировина для різних галузей промисловості). В Європі козівництво розвивається за рахунок впровадження у виробництво сучасних технологій утримання, механізованого доїння, селекційно-племінної робити, яка спрямована на поліпшення молочної продуктивності кіз, а також за рахунок створення ряду молокопереробних підприємств. На жаль, в Україні галузь перебуває на стадії формування і потребує додаткової уваги з боку науковців та держави. У даній статті проаналізовано статистичні дані щодо поголів'я кіз і сучасного стану розвитку галузі козівниитва в Україні, визначено основні кількісні показники продуктивності (надій молока), а також описано перспективи розвитку галузі в цілому. Запропоновано основні заходи з поліпшення ведення галузі, а саме: впровадження селекційних досягнень, механізаціі процесів утримання та доїння, профрілактики захворювань, формування культури споживання продуктів козівництва тощо. Крім того, на прикладі господарства «Мила кізонька Гай», що розташоване у Житомирській області продемонстровано модель розвитку фермерського господарства з утримання кіз. Визначено, що незважаючи на різні кризові фрактори у тваринництві і, зокрема, в козівництві галузь має потенціал до розвитку. В роботі використано статистичні та аналітичні методи досліджень.

Ключові слова: козівництво, поголів'я, порода, продукція, галузь тваринництва, сучасні тенденції.

DOI: https://doi.org/10.32845/bsnau.Ivst.2021.4.14

Козівництво - галузь тваринництва, яка займається розведенням кіз. Від кіз отримують молоко, м'ясо, шкіри, пух, вовну, інші види сировини. Козівництво поширене майже на всіх континентах.

Світове поголів'я кіз нині становить близько 1 млрд голів і постійно зростає. Так, на початку XX століття кіз у світі було 80 млн голів (із яких у Європі - 27,5\%), 1990 - 575 млн голів, 1997 - 703 млн голів (у Європі - $3 \%$ ), 2007 - 826 млн голів. В Україні в 1990 роках їх кількість становила 0,5 млн голів, а на початку 2012 року - 0,7 млн голів [6].

Нестабільність соціально-економічної ситуації, низький рівень концентрації капіталу в аграрній сфері, диспаритет цін між сільськогосподарською продукцією і продукцією промисловості та його наслідки зумовили тривалу депресію в цій галузі аграрного виробництва [11].

В процесі рефрормування агропромислового комплексу тваринництво України (в тому числі і козівництво) зазнало, на жаль, негативних змін. Масове скорочення поголів'я сільськогосподарських тварин, зниження продуктивності, збитковість виробництва та погіршення якості продукції ставлять під загрозу національну продовольчу безпеку, знижується експортний потенціал країни та погіршується соціальна ситуація в сільській місцевості [13].
Розвитку козівництва в Україні присвячено багато наукових досліджень та праць вітчизняних науковців, зокрема, В. Сербіної, А. Маслюка, Є. Данкевича, Л. Пірової, І. Ластовської, Л. Косіор, О. Борща та інших.

А. М. Маслюк із співавторами у своїй праці вказує на те, що: «Поголів'я кіз коливається в межах 570-600 тис. гол. В останні роки спостерігається тенденція до збільшення чисельності кіз у всіх категоріях господарств. Кози в господарствах України в основному молочного та комбінованого напрямів продуктивності» [7]

Слід зауважити ще й той факт, що розвиток галузі залежить від економічної ситуації в державі та кожного окремо взятого регіону в тому числі, і від платоспроможності населення, і від культури споживання продукції козівництва. Саме на вище зазначених тезисах акцентує увагу J.-P. Dubeuf із співавторами [15].

Варто зазначити, що відродженню галузі в Україні сприяли ряд факторів, серед яких невибагливість кіз до кормів, в т. ч. низький рівень споживання концентрованих кормів (у порівнянні з великою рогатою худобою) [10].

Враховуючи специфіку галузі та ситуацію в якій наразі перебуває галузь, залишається актуальним додатковий аналіз стану та результативності галузі козівництва.

Вісник Сумського національного аграрного університету 
Мета дослідження. Основною метою роботи є аналіз сучасного стану козівництва в Україні, визначення слабких та сильних сторін розвитку галузі.

Завдання досліджень - полягало в аналізі сучасного стану галузі козівництва в Україні.

Методи та матеріали досліджень. Матеріалом для досліджень слугували статистична документація. У ході роботи використовували статистичні та аналітичні методи досліджень.

Результати досліджень. У країнах Європи козівництво розвивається інтенсивними темпами на основі використання сучасних технологій (у тому числі механізоване доїння кіз, переробка отриманої сировини тощо) та селекційних досягнень (особливо французьких і голландських селекціонерів, які створили стада з надоями 1800-2000 кг молока). В європейських країнах частка козиного молока становить близько 30 \% від загальної кількості виробленого молока, а в арабських країнах вона досягає 50 \% і більше [4].

Найбільша кількість нині відомих порід (в межах 374) походять з Європи, з яких 59 - з Італії, 27 - Німеччини, 23 Іспанії, 20 - Великобританії та 18 - з Франції [10].

За даними Маслюка А. М. за чисельністю порід у світі провідне місце належить молочним породам - $37 \%$, молочно-м'ясним - 20, м'ясним - 14, м'ясо-вовновим - 9, пуховим - 9, м'ясо-шкурковим - 5, вовновим - 4, шкурковим - $2 \%$ відповідно. В Європейських країнах за чисельністю переважають молочні - 66,4 \% і молочно-м'ясні - 15,9 \% породи кіз, тоді як в Азії - комбіновані - більше 50 \% від загальної чисельності поголів'я, в Африцці - м'ясні породи [7].

В Україні найбільш поширені породи молочного напрямку продуктивності. Крім того, в різних регіонах існує безліч місцевих грубошерстих порід, основну продукцію яких складають м'ясо, молоко, пух і шкури [9]. Найбільшим попитом користуються такі молочні породи, як зааненська, тоггенбургська, чеська бура. Серед м'ясних порід популярністю користуються грецька та бурська породи [2].

Серед біологічних особливостей кіз варто визначити наступні: висока адаптивна здатність до різних умов середовища, використання малопродуктивних пасовищ, фізіологічна стійкість до багатьох захворювань, мають міцні ратиці; здатність перетравлювати корми з високим вмістом клітковини - до 60 \%, споживати найбільшу кількість видів рослин (біля 470 із 545), у порівнянні з іншими сільськогосподарськими тваринами [4].

Виробництво козиного молока у сільськогосподарських підприємствах України в 2020 році склало 1,7 тис. тонн і скоротилося на 0,4 \% у порівнянні з 2019 роком (дані Державної служби статистики України) $[1,5]$

За хімічним складом молоко кіз більш повноцінне порівняно з молоком корів: в ньому більше вдвічі альбумінів і глобулінів, значно менший розмір жирових кульок і частинок білка казеїну, що сприяє кращому засвоєнню його організмом людини. Кислотність козиного молока нижча, ніж у коров'ячого - через вміст білка на рівні (3,5-4 \%), кальцію і солей фосфору. Козине молоко $є$ сировиною для приготування різних сортів сиру, а також масла та кисло-молочних продуктів. Воно має бактерицидні властивості, нормалізує роботу шлунково-кишкового тракту, позитивно впливає на роботу серцево-судинної системи (за рахунок значного вмісту калію) [16].

При високому рівні розвитку галузі основна діяльність має бути спрямована на селекційно-племінну роботу, яка полягає у вирощуванні і реалізації племінного молодняку; проведенні генетичних досліджень; організації виставок з племінними тваринами тощо. Вище перераховані фактори повинні враховувати передові технологічні рішення, наявність переробних підприємств, мережу реалізації продукції [8].

Станом на сьогодення, козівництво в Україні перебуває в стані формування. Головними перешкодами для успішної реалізації наявного потенціалу сталого розвитку конкурентоспроможного козівництва $€$ малочисельність поголів'я (особливо високопродуктивного племінного) і низький потенціал продуктивності тварин в господарствах, недостатній рівень технологічного оснащення, незадовільний стан і нераціональне використання природних кормових угідь, недостатня кількість гільдій з переробки продукції і недостатнє економічна мотивація сільськогосподарських виробників [7].

Згідно даних Державної служби статистики України (таблиця 1) поступове зниження поголів'я кіз в Україні спостерігається з 2015 року. Станом на 2020 рік у господарствах усіх категорій нараховують 545,7 тис. голів кіз. Разом 3 тим, основне поголів'я зосереджене в приватних господарствах населення [5]

Таблиця 1.

Поголів'я кіз в Україні за 2015 -2020 рр., тис. голів.

\begin{tabular}{|l|c|c|c|}
\hline \multicolumn{1}{|c|}{ Роки } & \multicolumn{1}{|c|}{ Всього } & У господарствах населення & У сільгосппідприємствах \\
\hline 2015 & 585,6 & 580 & 4,7 \\
\hline 2017 & 595,9 & 588,1 & 7,8 \\
\hline 2018 & 582,1 & 573,2 & 8,9 \\
\hline 2019 & 570,1 & 560,3 & 9,8 \\
\hline 2020 & 545,7 & 535,9 & 9,8 \\
\hline
\end{tabular}

Примітка: станом на 1 січня 2020 року, за винятком тимчасово окупованих територій Донецької, Луганської областей та АР Крим.

Зокрема, в господарствах населення станом на 2020 рік утримується 535,9 тис. голів, що на 44,1 тис голів менше, ніж за аналогічний період 2019 року. За чисельністю поголів'я кіз в розрізі областей, найбільше їх утримується в Одеській області - 68,4 тис. голів, а найменше в Тернопільській області - 11,6 тис. гол. відповідно. Щодо Житомирської області, то загальне поголів'я нараховує 16,9 тис. голів [3, 5].

Одним із фракторів збільшення позитивної динаміки розвитку козівництва є створення малих ферм, які будуть технологічно оснащені для промислової технології виробни- цтва молока. Попередні розрахунки вказують на те, що за реалізації основних засад підвищення молочної продуктивності дійних кіз, виробництво молока у господарствах такого типу може зрости до 70 т/рік [13].

Важливою частиною розвитку $є$ існування місцевих порід кіз для чистопородного схрещування. За результатами аналізу міжнародного та вітчизняного досвіду молочного козівництва, Україна визначила чотири основні перспективні породи молочних кіз для чистопородного розведення та покращення місцевого тваринництва: з них виведено заане- 
нську, альпійську, тоггенбурзьку, англо-нубійську та європейську [12].

Станом на 2021 рік в Україні $€ 7$ господарств, що отримали статус племінного репродуктора. Загальна чисельність козематок - більше 1000 голів порід: зааненської, альпійської та англо-нубійської. Ще 10 господарств за кількістю поголів'я, середньодобовою продуктивністю і рівнем селекції в найближчий час можуть пройти атестацію на ста- тус племрепродуктора [8].

Моделлю розвитку сучасного господарства, що спеціалізується на розведенні кіз є ТОВ «Мила кізонька Гай», що розташоване в Житомирській області та було засновано у липні 2017 року. Господарство спеціалізується на розведенні кіз молочного напрямку продуктивності зааненської породи. Господарські показники діяльності підприємства подано в таблиці 2.

Господарські показники діяльності ТОВ «Мила кізонька Гай»

Таблиця 2

\begin{tabular}{|c|c|c|}
\hline \multirow{2}{*}{ Показник } & \multicolumn{2}{|c|}{ Роки } \\
\cline { 2 - 3 } & 2019 & 2020 \\
\hline Поголів'я, гол. & 120 & 80 \\
\hline в т.ч. маточне, гол. & 70 & 3,2 \\
\hline Середньодобовий надій, л & 3,1 & 81920 \\
\hline Валовий надій, л & 65100 & 3,7 \\
\hline Жирність, $\%$ & 3,55 & \\
\hline
\end{tabular}

Зокрема, у виробничій діяльності господарства спостерігається позитивна динаміка. Так, станом на 2020 рік загальна чисельність поголів'я зросла на 21 голову (в т. ч. маточного на 10 голів). Збільшився середньодобовий надій 3 3,1 л у 2019 р. до 3,2 л у 2020 р., а валовий з 65100 л до 81920 л, показник жирності зріс з 3,55 \% до 3,7 \% відповідно. Наразі вихід козенят на 100 козематок складає 151 голову. Варто зазначити, що перспективним планом розвитку підприємства до 2024 року передбачено збільшення поголів'я до 500 голів. У господарстві застосовується стійловопасовищна система утримання (взимку кози утримуються у приміщеннях, а влітку перебувають на пасовищі). Кормова база господарства представлена грубими, соковитими, концентрованими кормами та мінеральними добавками. Дорослі особини споживають на добу: 5-8 кг зеленого корму влітку і 1-2,5 кг, грубого - взимку, концентрованого - 0,3-1 кг (у вигляді вологих мішанок), соковитих (буряк кормовий, ріпа, капуста) - 2-4 кг. 3 мінеральних добавок згодовують кухонну сіль молодняку - 6-10 г, дорослим - 10-15 г, крейду 7-10 г на голову/добу відповідно. Кормовий стіл для кіз пе- редбачає обладнані двоярусні годівниці: верхній ярус - для грубих кормів, нижній - для концентратів і соковитих кормів. 3 місячного віку козенят поступово починають привчати до поїдання різних видів корму. Відлучають молодняк від козематок при досягненні ними живої маси 18-20 кг. Операція доїння - механізована. Молоко реалізується на молокопереробний пункт.

Висновок. Для підвищення селекційної роботи та прискорення формування галузі козівництва в Україні доцільно створити асоціацію молочного козівництва з науковим центром та міжнародними зв'язками на основі формувань фермерського типу. Використовувати прогресивні технології утримання тварин, переробки продукції козівництва з врахуванням сучасних світових тенденцій.

Подальші дослідження повинні бути спрямовані на вивчення і впровадження досвіду іноземних науковців та практиків щодо ведення галузі козівництва за інтенсивними технологіями та переробки продукції 3 метою створення господарства із замкненим циклом.

Список використаної літератури:

1. Агротаймс. Тваринництво. URL : https://agrotimes.ua/tvarinnitstvo/u-2020-roczi-silgosppidpryyemstva-vyrobyly-17-tystonn-kozynogo-molokal.

2. Види, породи кіз : опис і фотографії. Агросмарт. Веб-сайт. URL : https://agro-smart.com.ua/ua/news/vidy--porodykoz--opisanie-i-fotografii.

3. В Україні зменшилось поголів'я кіз та овець. Агрополіт. Веб-сайт. URL : https://agropolit.com/news/17085-v-ukrayinizmenshilos-pogolivya-kiz-ta-ovets.

4. Гузєєв Ю. В., Вінничук Д. Т. Козівництво - перспективна галузь тваринництва України. Тваринництво, кормовиробництво, збереження та переробка продукції тваринництва. Таврійський науковий вісник : Науковий журнал. Вип. 83. Херсон : Грінь Д.С. 2013. С. 161-165.

5. Державна служба статистики України. Статистичний збірник : Тваринництво України 2019. Київ, 2020. URL : http://www.ukrstat.gov.ua/druk/publicat/kat_u/2020/zb/05/zb tvaryny_2019.pdf.

6. Козівництво. Енциклопедія сучасної України : URL : https://esu.com.ua/search_articles.php?id=8212. (дата звернення 26.11.2021).

7. Маслюк А. М., Атановська-Маслюк О. Й., Зіневич. В. М. Стан козівництва у світі, перспективи розвитку та наукове забезпечення в Україні. Козівництво : Інститут тваринництва степових районів імені М. Ф. Іванова «Асканія-Нова». Національний науковий селекційно-генетичний центр 3 вівчарства. Асканія-Нова, 2020. C. 238-254. DOI : https://doi.org/10.33694/2415-3958-2020-1-5-238-254

8. Міцніють попри все. Аграрний тиждень. Україна. URL : https://a7d.com.ua/tvarinnictvo/39713-mcnyut-poprivse.html(дата звернення 26.11.2021).

9. Основні породи кіз. Веб-сайт. URL : https://pidru4niki.com/1791040762402/tovaroznavstvo/osnovni_porodi_kiz.

10. Передерій В. Р., Шаферівський Б. С. Стан і перспективи розвитку козівницта в Україні та Cвіті. URL : http://dspace.pdaa.1edu.ua:8080/bitstream/123456789/10633/1/\%D0\%A2\%D0\%B5\%D0\%B7\%D0\%B8\%20\%20\%D0\%9F\%D0\%B5 
11. Пуцентейло П. Р. Особливості функціонування галузі м'ясного скотарства в умовах кризи : зб. наук. праць ТДАУ. За ред. В. А. Рульєва. М. : Вид-во Мелітопольська типографія «Люкс», 2010. № 2 (10). 446 с.

12. Сербіна В. О. Історія та сучасний стан козівництва в Україні : Науковий вісник «Асканія-Нова». Вип. 5. Част.1 : «ПИЕЛ», 2012. С. 196-200.

13. Сучасні тенденції розвитку тваринництва в Україні. Ефрективна економіка. URL http://www.economy.nayka.com.ua/?op=1\&z=2267(дата звернення 26.11.2021).

14. Чи $є$ перспективи в козинного молока України? Agravery. Аграрне інфрормаційне агентство : URL : https://agravery.com/uk/posts/show/ci-e-perspektivi-v-kozinogo-moloka-v-ukraini.(датазвернення 26.11.2021).

15. Dubeuf, J.-P., Morand-Fehr, P., Rubino, R. Small Ruminant Research. Situation, changes and future of goat industry around the world. Vol. 51. Is. 2. 2004. p.165-173. DOI : https://doi.org/10.1016/j.smallrumres.2003.08.007

16. Ryzhkova, T., Dyukareva, G., Heyda, I., \& Goncharova, І. Порівняльна характеристика фрізико-хімічних показників козиного і коров'ячого молока промислового призначення. Ветеринарія, технології тваринництва та природокористування. (3). 2019. 213-224. DOI : https://doi.org/10.31890/vttp.2019.03.29

\section{References:}

1. Ahrotaims. Tvarynnytstvo. [Agrotimes. Livestock]. URL : https:/lagrotimes.ua/tvarinnitstvo/u-2020-roczisilgosppidpryyemstva-vyrobyly-17-tys-tonn-kozynogo-molokal.

2. Vydy, porody kiz : opys i fotohrafii [Species, breeds of goats : description and photos]. Ahrosmart [Agrosmart]. Veb-sait. URL : https://agro-smart.com.ua/ua/news/vidy--porody-koz--opisanie-i-fotografii.

3. V Ukraini zmenshylos poholivia kiz ta ovets. [The number of goats and sheep has decreased in Ukraine]. Ahropolit [Agropolit]. Veb-sait. URL : https://agropolit.com/news/17085-v-ukrayini-zmenshilos-pogolivya-kiz-ta-ovets.

4. Huzieiev, Yu. V., Vinnychuk, D. T. Kozivnytstvo. (2013). Perspektyvna haluz tvarynnytstva Ukrainy [Goat breeding is a promising branch of animal husbandry in Ukraine]. Tvarynnytstvo, kormovyrobnytstvo, zberezhennia ta pererobka produktsii tvarynnytstva [Livestock, feed production, storage and processing of livestock products]. Tavriiskyi naukovyi zbirnyk [Taurian scientific collection]. Vyp. 83. 161-165.

5. Derzhavna sluzhba statystyky Ukrain. [State Statistics Service of Ukraine.]. Statystychnyi zbirnyk [Statistical collection] : Tvarynnytstvo Ukrainy [Livestock of Ukraine]

http://www.ukrstat.gov.ua/druk/publicat/kat_u/2020/zb/05/zb_tvaryny_2019.pdf.

6. Kozivnytstvo: Entsyklopediia suchasnoi Ukrainy [Goat breeding: Encyclopedia of modern Ukraine]. Veb-sait. URL : https://esu.com.ua/search_articles.php?id=8212 .

7. Masliuk, A. M., Atanovska-Masliuk, O.I. Zinevych, V.M. (2020). Stan kozivnytstva u sviti, perspektyvy rozvytku ta naukove zabezpechennia v Ukraini [The state of goat breeding in the world, development prospects and scientific support in Ukraine]. Kozivnytstvo [Goat breeding]: Instytut tvarynnytstva stepovykh raioniv imeni M. F. Ivanova «Askaniia-Nova» - Natsionalnyi naukovyi selektsiino-henetychnyi tsentr z vivcharstva. [Askania-Nova MF Ivanov Institute of Steppe Animal Husbandry - National Scientific Breeding and Genetics Center for Sheep Breeding.] Askaniia-Nova. DOI : https://doi.org/10.33694/2415-3958-2020-1-5$\underline{238-254}$

8. Mitsniiut popry vse [Strengthen in spite of everything]. Ahrarnyi tyzhden [Agrarian week]. Veb-sait. URL : https://a7d.com.ua/tvarinnictvo/39713-mcnyut-popri-vse.html

9. Osnovni pordy kiz [The main breeds of goats]. Veb-sait. URL

https://pidru4niki.com/1791040762402/tovaroznavstvo/osnovni_porodi_kiz

10. Perederii, V. R., Shaferivskyi, B. S. Stan i perspektyvy rozvytku kozivnytsta v Ukraini ta sviti. [Status and prospects of goat breeding in Ukraine and the world]. Veb-sait URL http://dspace.pdaa.1edu.ua:8080/bitstream/123456789/10633/1/\%D0\%A2\%D0\%B5\%D0\%B7\%D0\%B8\%20\%20\%D0\%9F\%D0\%B5 \%D1\%80\%D0\%B5\%D0\%B4\%D0\%B5\%D1\%80\%D1\%96\%D0\%B9\%20\%D0\%92.\%D0\%A0..pdf .

11. Putsenteilo, P. R. (2010). Osoblyvosti funktsionuvannia haluzi miasnoho skotarstva v umovakh kryzy [Features of the functioning of the meat industry in a crisis]. Zb. nauk. prats TDAU. [Collection of scientific works of TSAU. Edited by. V.A. Rudder]. Vyp.2. 446.

12. Serbina, V. O. (2012). Istoriia ta suchasnyi stan kozivnytstva v Ukraini [History and current state of goat breeding in Ukraine]. Naukovyi visnyk «Askaniia-Nova». [Scientific Bulletin "Askania-Nova"]. Vyp.5.196-200.

13. Suchasni tendentsii rozvytku tvarynnytstva v Ukraini [Current trends in livestock development in Ukraine]. Efektyvna ekonomika [Efficient economy]. Veb-sait. URL : http://www.economy.nayka.com.ua/?op=1\&z=2267

14. Chy ye perspektyvy v kozynnoho moloka Ukrainy? [Are there any prospects for goat's milk in Ukraine?]. Agravery: ahrarne informatsiine ahenstvo [Agravery Agrarian News Agency]. Veb-sait. URL : https://agravery.com/uk/posts/show/ci-e-perspektiviv-kozinogo-moloka-v-ukraini

15. Dubeuf, J.-P., Morand-Fehr, P. Rubino, R. (2004). Situation, changes and future of goat industry around the world. p. 165-173. . DOI : https://doi.org/10.1016/i.smallrumres.2003.08.007

16. Ryzhkova, T., Dyukareva, G., Heyda, I., \& Goncharova, I. (2019). Porivnialna kharakterystyka fizyko-khimichnykh pokaznykiv kozynoho I korov'iachoho moloka promyslovoho pryznachennia [Comparative characteristics of physicochemical parameters of industrial goat's and cow`s milk]. Veterynariia, tekhnolohii tvarynnytstva ta pryrodokorystuvannia [Veterinary medicine, animal husbandry technologies and nature management]. Vyp.3. 213-224. DOI : https://doi.org/10.31890/vttp.2019.03.29.

Kovalchuk Iryna Igorevna, PhD of Veterinary Sciences, Senior Lecturer 
Kovalchuk Igor Vasulevich, PhD of Agricultural Sciences, Docent

Morochkivska Anastasiy Valentunivna, Master's student of the Faculty Technology

Polissia National University (Zhytomyr, Ukraine)

Current state and aspects of development of the goat breeding industry

One of the leading industries in providing food to the population is goat breeding. In countries with developed livestock farming, goat breeding is an important branch of agriculture, due to its polyproductivity (food source - milk, cheese, fat and raw materials for various industries). In Europe, goat breeding is developing due to the introduction of modern technologies of keeping, mechanized milking, selection and breeding work, which is aimed at improving the milk productivity of goats, as well as through the creation of a number of milk processing enterprises. Unfortunately, in Ukraine the industry is in the process of shaping and require additional attention from scientists and the state. This article analyzes the statistics on the number of goats and the current state of development of the goat farming in Ukraine, defined the main quantitative indicators of productivity (milk yield), and describes the aspects of the industry development. The main goals to improve the development of the industry are proposed: introduction of selection achievements, mechanization of maintenance and milking processes, disease prevention, formation of consumption culture of goat products, etc. In addition, the development model of goat farm was demonstrated on the example of the farm "Mila Kizonka Gai» located in Zhytomyr region. It is determined that despite various crisis factors in livestock farming and, in particular, in goat breeding, the industry has the potential for development. Statistical and analytical research methods are used in the work.

Key words: goat breeding, livestock, breed, products, livestock industry, modern trends.

Дата надходження до редакції: 01.12.2021 p. 